\title{
Catchment features controlling nitrogen dynamics in running waters above the tree line (central Italian Alps)
}

\author{
R. Balestrini ${ }^{1}$, C. Arese $^{1}$, M. Freppaz ${ }^{2}$, and A. Buffagni ${ }^{1}$ \\ ${ }^{1}$ Water Research Institute (IRSA-CNR), Brugherio (MB), Italy \\ ${ }^{2}$ Università degli Studi di Torino, DISAFA and NatRisk - Laboratorio Neve Suoli Alpini, Grugliasco (TO), Italy
}

Correspondence to: R. Balestrini (balestrini@irsa.cnr.it)

Received: 13 July 2012 - Published in Hydrol. Earth Syst. Sci. Discuss.: 18 September 2012

Revised: 6 February 2013 - Accepted: 8 February 2013 - Published: 7 March 2013

\begin{abstract}
The study of nitrogen cycling in mountain areas has a long tradition, as it was applied to better understand and describe ecosystem functioning, as well as to quantify long-distance effects of human activities on remote environments. Nonetheless, very few studies, especially in Europe, have considered catchment features controlling nitrogen dynamics above the tree line with focus on running waters.

In this study, relationships between some water chemistry descriptors - including nitrogen species and dissolved organic carbon (DOC) - and catchment characteristics were evaluated for a range of sites located above the tree line (1950-2650 ma.s.l.) at Val Masino, in the central Italian Alps. Land cover categories as well as elevation and slope were assessed at each site. Water samples were collected during the 2007 and 2008 snow free periods, with a nearly monthly frequency. In contrast to dissolved organic nitrogen, nitrate concentrations in running waters showed a spatial pattern strictly connected to the fractional extension of tundra and talus in each basin. Exponential models significantly described the relationships between maximum $\mathrm{NO}_{3}$ and the fraction of vegetated soil cover (negative relation) and talus (positive relation), explaining almost $90 \%$ of nitrate variation in running waters. Similarly to nitrate but with an opposite behavior, DOC was positively correlated with vegetated soil cover and negatively correlated with talus. Therefore, land cover can be considered one of the most important factors affecting water quality in high-elevation catchments with contrasting effects on $\mathrm{N}$ and $\mathrm{C}$ pools.
\end{abstract}

\section{Introduction}

Human activities have dramatically altered the nitrogen $(\mathrm{N})$ cycle by increasing the rate of transformation of $\mathrm{N}_{2}$ into reactive nitrogen (RN) that includes all the biologically functional $\mathrm{N}$ forms. From the late 19th to the late 20th century, the amount of RN derived mainly from food and energy production increased globally by an order of magnitude ( $\mathrm{Gal}-$ loway et al., 2004). On a global scale, atmospheric transport and subsequent deposition have become the dominant $\mathrm{N}$ distribution processes, and increasing atmospheric $\mathrm{N}$ deposition occurs over so much of the earth's surface that the cumulative effects amount to global-scale change.

Most alpine regions, both in Europe and in the United States, receive $\mathrm{N}$ deposition rates exceeding $0.5 \mathrm{~kg} \mathrm{~N} \mathrm{ha}^{-1} \mathrm{yr}^{-1}$, the expected level for ecosystems in the absence of human influence (Burns, 2003; Fenn et al., 2003; Hiltbrunner et al., 2005; Balestrini et al., 2006). Historically, $\mathrm{N}$ limited, high-elevation ecosystems show symptoms of $\mathrm{N}$ saturation at relatively low $\mathrm{N}$ deposition rates (2$\left.4 \mathrm{~kg} \mathrm{Nha}^{-1} \mathrm{yr}^{-1}\right)$, as in the case of the Rocky Mountains (Williams et al., 1996). The fluxes reported for European Alpine sites at elevation above $2000 \mathrm{~m}$ a.s.l. are between 0.5 $3 \mathrm{~kg} \mathrm{Nha}^{-1} \mathrm{yr}^{-1}$ (Filippa et al., 2010), but at lower altitude sites these rates greatly increase (Hiltbrunner et al., 2005; Rogora et al., 2008).

Mountain ecosystems, in particular the landscape above the tree line, are highly vulnerable to changes in climate, pollutants and nutrient input. Complex topography, harsh climate, extensive snow cover and a short growing season, all contribute in reducing the ability of these ecosystems to face alterations that affect their physical structure and biological 
communities. These extreme environments are also key components of the water cycle since they supply drinking water to major metropolitan areas worldwide.

While the effects of $\mathrm{N}$ deposition on forest ecosystems have been studied extensively, analogous studies in highelevation areas are scarce partly because of the logistical constraints in carrying out field sampling campaigns in such isolated environments. Intensive and long-term research on $\mathrm{N}$ cycling in alpine ecosystems have been carried out in the United States (Brooks and Williams, 1999; Williams et al., 2011), but to date only few studies are available from high-elevation areas in the European Alps (Psenner, 1989; Tockner et al., 2002; Kopacek et al., 2005). Most of them provide $\mathrm{N}$ concentrations in snowpack (Hiltbrunner et al., 2005; Kuhn et al., 1998) or from ice cores drilled in glaciers (Schwikowski et al., 1999).

A significant environmental indicator of $\mathrm{N}$ saturation, the condition in which the availability of inorganic $\mathrm{N}$ exceeds the $\mathrm{N}$ assimilation capacity of biological processes (Aber et al., 1998), is the temporal variation of nitrate $\left(\mathrm{NO}_{3}\right)$ in the waters of uncontaminated catchments (Traaen and Stoddard, 1995). In N-limited systems, $\mathrm{NO}_{3}$ concentrations are very low with slight seasonal variations between vegetative and dormant periods. Several studies have associated changes in surface water chemistry with increased $\mathrm{N}$ deposition (Dise and Wright, 1995). However, establishing the cause of changes in stream water chemistry in high-elevation ecosystems is not simple. Recent studies on the microbiology of alpine soils suggest an important role of bacterial communities in controlling $\mathrm{N}$ cycling and $\mathrm{NO}_{3}$ export in these basins (Lipson et al., 1999; Nemergut et al., 2005). Physical features of the catchment strongly influence the chemical composition of stream water, and may control ecosystem responses to global perturbations, such as atmospheric $\mathrm{N}$ deposition and/or changes in climate (Clow and Sueker, 2000; Lovett et al., 2000; Sickman et al., 2002; Lewis, 2002; Kopaceck et al., 2005; Helliwell et al., 2007). The importance of physical landscape components in the amplification and attenuation of biogeochemical processes has been recently highlighted in a conceptual model for high-elevation ecosystems named "Landscape Continuum Model" (Seastedt et al., 2004). The model was developed to predict where inorganic and organic matter is likely to accumulate or be exported, and emphasizes the downward transfer of water and nutrients via physical transport vectors such as rivers, wind, rockslides, and snow avalanches. It provides a mechanistic interpretation explaining how different portions of the high-elevation landscape can experience excesses and limitations of the same nutrient, e.g. $\mathrm{N}$, also in response to global changes.

Given the increasing availability of digital thematic maps and geographic information systems, the analysis of relationships between stream water chemistry and a wide variety of physical features of basins is now easier than in the past. This type of analysis can be very useful to identify habitat and catchment features influencing $\mathrm{N}$ retention in high-elevation ecosystems. The possibility to find powerful predictors of $\mathrm{N}$ fluxes and concentrations, together with the development of statistical models, becomes very interesting especially for lakes and streams that are rather inaccessible, such as those at high altitude. This approach could enhance our knowledge of the impact of increased $\mathrm{N}$ deposition on water quality upscaling the results obtained from intensively studied areas to regional scale.

In the present study, we investigate the relations between some descriptors of water chemistry, including $\mathrm{N}$ species, and some catchment physical variables at 16 sites located in a high-elevation valley of the central Italian Alps. Since 1994, a number of investigations have been performed in this valley (Val Masino) at lower elevations (1190 m a.s.l.) in order to understand interactions between atmospheric fluxes and the forest compartment (Balestrini et al., 2001, 2002). Given an atmospheric $\mathrm{N}$ input equal to $15 \mathrm{~kg} \mathrm{Nha}^{-1} \mathrm{yr}^{-1}$, several findings, in particular the strong soil $\mathrm{N}$ retention, seem to indicate a $\mathrm{N}$-limited status of the forested portion of the basin. Other observations, such as monthly $\mathrm{NO}_{3}$ concentrations in the river Masino, point in the opposite direction suggesting a surplus of $\mathrm{N}$ bioavailability in the terrestrial ecosystem (Balestrini et al., 2006). Our aims are to characterize the chemical composition of the running waters at the upper basin of river Masino, and to test the hypothesis that $\mathrm{N}$ water chemistry and $\mathrm{N}$ retention capacity could be predicted using some environmental and terrain variables.

\section{Material and methods}

\subsection{Study area}

The study area is located in the upper basin of the river Masino (northern Italy), a typical glacial valley (Val Masino) extending for $25.2 \mathrm{~km}^{2}$ on the north side of the main valley, Valtellina. Around $85 \%$ of the basin of Val Masino is above $1850 \mathrm{~m}$ a.s.l. and is delimited by three Alpine glacial cirques with peaks rising to $3400 \mathrm{~m}$ a.s.l. A substantial shrinkage of glaciers occurred in this area, like most of the glaciers in the European Alps (Cannone et al., 2008) and, at present, the glaciers occupy less than $5 \%$ of the basin. At the lower limit of Alpine meadows (around $2400 \mathrm{~m}$ a.s.l.) the vegetation is characterized almost exclusively by herbaceous species with a predominance of Carex curvula and Nardus stricta. Most of these natural grasslands above the treeline have been subjected to grazing until the 1960s. Moving upwards the turf is fragmented into individual clumps, initially more dense and confluent, then more isolated and scattered. At altitudes higher than $2500 \mathrm{~m}$ prairie species are replaced by plants adapted to live on screes or in the interstices between stones. The most represented species in this area are acidophilic (e.g. Cryptogramma crispa, Oxyria digyna, Rumex scutatus, Saxifraga bryoides). 
The overall soil cover of the catchment is $66 \%$ and only $13 \%$ of the catchment is forested. The soils developed on a volcanic granodiorite also called ghiandone and are characterized by significant organic matter contents in the upper horizons.

Another study area (Bagni di Masino) belonging to the LTER ( Long Term Ecological Research) and ICP-Forest (International Co-operative Program) networks is located at lower elevations (1190 m a.s.l.), within the river Masino basin. A number of monitoring studies have been carried out within these programmes, including throughfall and open field deposition measurements, chemical and hydrological monitoring of river Masino, soil solution and litterfall chemical characterization (Balestrini et al., 2000, 2002, 2006; Balestrini and Tagliaferri, 2001). In particular, at the Bagni di Masino study site, the mean annual precipitation during the period from 1995 to 2008 was $1589 \mathrm{~mm} \mathrm{yr}^{-1} ; 30 \%$ of it occurred as snowfall from November to April. The climate is continental, with the highest amount of precipitation in summer and the least in winter. The mean annual air temperature is $+7{ }^{\circ} \mathrm{C}$.

\subsection{Sampling and analysis}

In order to select the sampling sites for the seasonal monitoring a preliminary campaign was conducted in the upper Val Masino basin (2000-2650 m a.s.1.) in June 2007 (Fig. 1). On the basis of the preliminary results obtained, sixteen sites were chosen in order to cover different land use categories and an elevation range of 2000-2650 m a.s.l. They were sampled with a nearly monthly frequency throughout the snow free period (from the end of June till October) in 2007 and 2008.

The analyses were performed on filtered samples $(0.45 \mu \mathrm{m})$, except for measurements of electrical conductivity and $\mathrm{pH}$. The alkalinity of samples with $\mathrm{pH}>5.6$ was measured by two-endpoint potentiometric titration with $\mathrm{HCl}$. $\mathrm{NH}_{4}$ was analysed by molecular absorption spectrometry (Perkin Elmer UV-VIS Lambda25) using the indophenolblue method. $\mathrm{NO}_{3}, \mathrm{SO}_{4}$ and $\mathrm{Cl}$ were determined by ion chromatography using a Dionex LC25 equipped with an AS11 column and $\mathrm{KOH}$ eluent. $\mathrm{Ca}, \mathrm{Mg}, \mathrm{Na}$ and $\mathrm{K}$ were measured by a Dionex ICS2000 ion chromatograph with a CS12 column. Total dissolved nitrogen (TDN) was measured using molecular absorption spectrometry UV-VIS, after a persulphate digestion in an autoclave at $120^{\circ} \mathrm{C}$. Dissolved organic nitrogen (DON) was estimated from the difference between TDN and inorganic $\mathrm{N}\left(\mathrm{NH}_{4}\right.$ plus $\left.\mathrm{NO}_{3}\right)$.

Dissolved organic carbon (DOC) was assayed by high temperature catalytic oxidation using a Shimadzu TOC$5000 \mathrm{~A}$ analyser.

The quality of chemical analyses was checked by including method blanks, repeated measurements of internal and certified reference samples and by regular interlaboratory tests and international intercomparisons (Marchetto et al.,

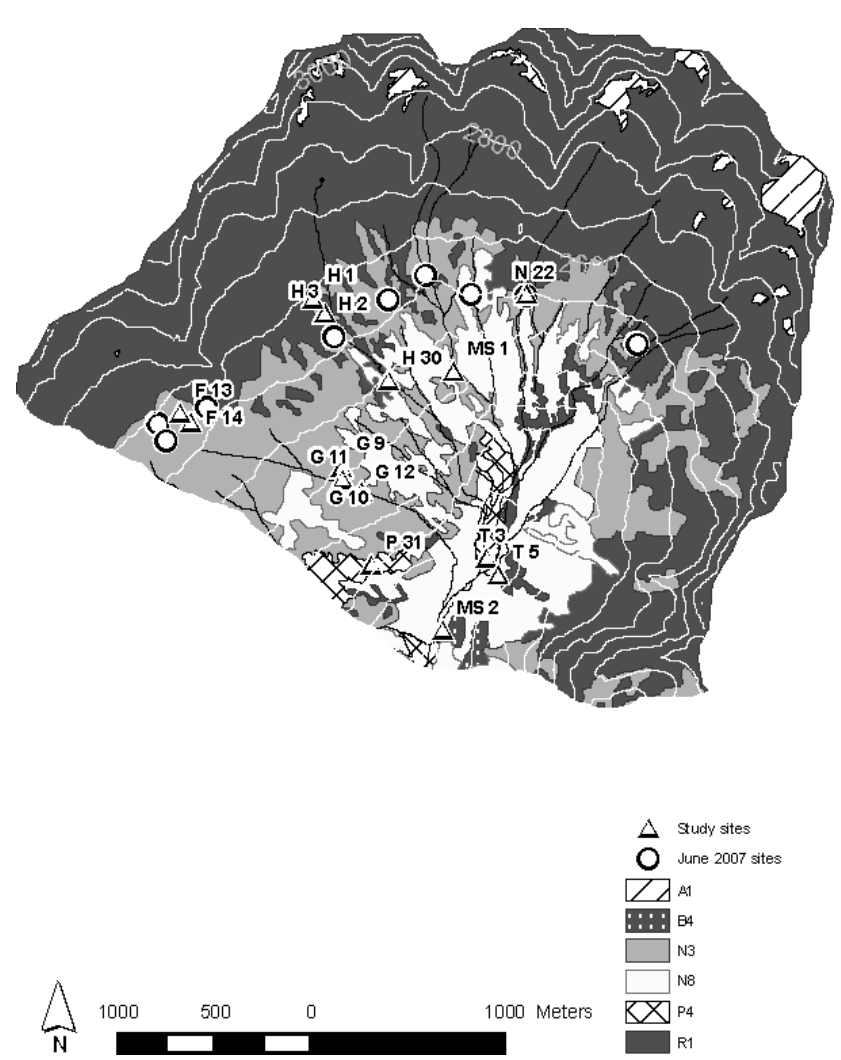

Fig. 1. Map of the of the Masino stream upper basin, indicating the location of the sampling sites and the land cover categories $(\mathrm{A} 1=$ Glaciers and snowfields, B4 $=$ Coniferous forest, N3 = Vegetation on rocks and rock debris, N8 = Shrub vegetation, $\mathrm{P} 4=$ Meadow vegetation, $\mathrm{R} 1=$ Rock debris and bedrock).

2006). The repeatabilities, based on repeated measurements of internal quality controls at different concentrations, were $3 \%$ for $\mathrm{NH}_{4}-\mathrm{N}, 2 \%$ for $\mathrm{NO}_{3}-\mathrm{N}, 4 \%$ for TDN, $3 \%$ for $\mathrm{SO}_{4}$, $6 \%$ for $\mathrm{Cl}$. Detection limits were $0.35 \mu \mathrm{eq} \mathrm{L}^{-1}$ for $\mathrm{NH}_{4}-\mathrm{N}$, $1.4 \mu$ eq $\mathrm{L}^{-1}$ for $\mathrm{NO}_{3}-\mathrm{N}, 0.56 \mu$ eq $\mathrm{L}^{-1}$ for $\mathrm{Cl}, 1.0 \mu \mathrm{eq} \mathrm{L}^{-1}$ for $\mathrm{SO}_{4}$ and $7.1 \mu \mathrm{mol} \mathrm{L}-1$ for TDN.

A geographic information system (GIS) was used to delineate the catchment for each sampling site. Topographic coverages were derived from digitized regional technical maps, which have a scale of $1: 10000$. We used a $20 \mathrm{~m}$ digital elevation model (DEM) for deriving the average slope, aspect and elevation for each basin. Basin land cover characteristics were quantified using a digital map with a scale of $1: 10000$ (DUSAF 1.1 - Regione Lombardia, 2001). From this map, 7 categories were identified and basin specific land use percentages were determined (Table 1).

\subsection{Estimation of $\mathrm{NO}_{3}$ retention}

We used an approach based on the comparison between $\mathrm{NO}_{3}$ and a geochemical descriptor $(\mathrm{Ca})$ in order to infer the removal of nitrate by biological processes. Normally, $\mathrm{Cl}$ is used as a conservative tracer to quantify the variations of $\mathrm{NO}_{3}$ 
Table 1. Land cover categories used to characterize the study basin.

\begin{tabular}{ll}
\hline & Land cover \\
\hline A1 & Glaciers and snowfields \\
A2 & Lakes and ponds \\
N3 & $\begin{array}{l}\text { Herbaceous vegetation on rock debris, } \\
\text { discontinuous and sparse }\end{array}$ \\
R1 & Rock debris and bedrock without \\
& vegetation \\
N8 & Herbaceous and/or shrub vegetation \\
P4 & Meadow vegetation \\
B4 & Coniferous forest \\
\hline
\end{tabular}

due to dilution or evaporative processes in studies on subsurface aquifers and groundwater (e.g. Sabater et al., 2003; Balestrini et al., 2011). Similarly, other authors, e.g. Lafreniere and Sharp (2005) used the difference in the $\mathrm{NO}_{3}: \mathrm{Cl}$ ratio between snow and streams as an indication of the effect of catchment processes on $\mathrm{NO}_{3}$ export to streams. In our study the $\mathrm{Cl}$ concentrations measured during June-October were very low and constant in all sites, with small variations mostly due to the analytical variability. This suggested that the temporal variations of $\mathrm{NO}_{3}$ were not due to physical processes such as evaporation or dilution. On the other hand, $\mathrm{NO}_{3}$, as well as some geochemical descriptors such as $\mathrm{Ca}$ first of all, and $\mathrm{Mg}$ and $\mathrm{SO}_{4}$, showed a similar trend with maximum concentration during October. Thus, assuming that the variations of $\mathrm{Ca}$ were principally due to weathering and/or soil leaching, we used the ratios $\mathrm{NO}_{3}$ : Ca to distinguish biological removal of $\mathrm{NO}_{3}$ from other processes. We used the $\mathrm{NO}_{3}$ : Ca ratio measured in June to derive expected values for other months. An example for July is reported below.

expected $\mathrm{NO}_{3 \mathrm{Jul}}=\mathrm{Ca} \mathrm{Jul}_{\mathrm{l}} \times\left(\mathrm{NO}_{3 \mathrm{Jun}} / \mathrm{Ca} \mathrm{Jun}\right)$

The data obtained in late June can be a common basis for almost all sites as they represent a condition where the running waters are mainly composed of water from melting snow after the effect of "ionic pulse" during the first spring thawing. Expected values higher than measured values indicate consumption of $\mathrm{NO}_{3}$ by biological processes, while the contrary indicates a biological production of $\mathrm{NO}_{3}$, e.g. nitrification. The percentage $\mathrm{NO}_{3}$ retention for each site was calculated as the mean ratio between measured and estimated concentration for all sampling dates in 2008. Results from 2007 were omitted because June samples were available for few sites only.

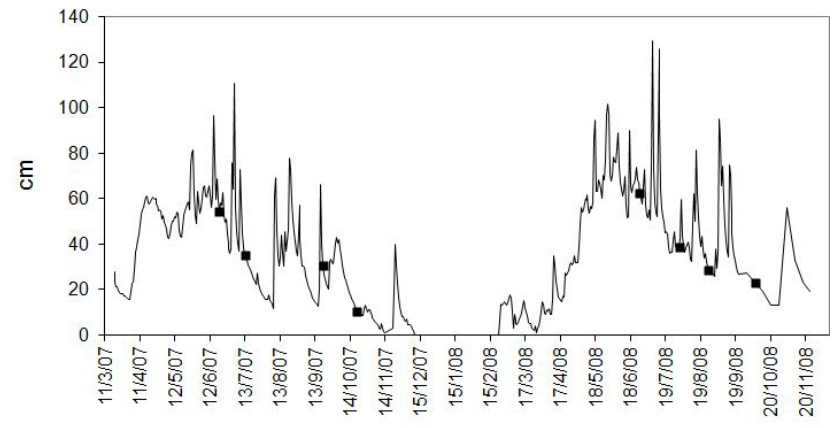

Fig. 2. Stream annual hydrograph (Masino stream) as hydrometric height $(\mathrm{cm})$. The dots refer to sampling campaigns.

\section{Results}

\subsection{Hydrology and catchment features}

At Bagni di Masino site, the amounts of precipitation during 2007 and 2008 were $1321 \mathrm{~mm}$ (15\% as snow) and $1926 \mathrm{~mm}$ ( $28 \%$ as snow), respectively, thus $17 \%$ less and $21 \%$ more than the long-term average $\left(1589 \mathrm{~mm} \mathrm{yr}^{-1}\right)$. The snowfall period was longer in 2008 (from the beginning of December to middle May) than the previous year (from the beginning of December till the middle of April).

The Masino river annual hydrograph for 2007 and 2008 (Fig. 2) reflects the typical seasonal trend for snowmelt dominated catchments. After the winter base flow, discharge begins to increase during April-May with the beginning of spring snowmelt, and peaks in late June. The autumn decline is often interrupted by some peaks due to intense November rainfall events. The annual median hydrometric height at Bagni di Masino was 16 and $28 \mathrm{~cm}$ during 2007 and 2008, respectively.

Table 2 shows the morphological and topographic features of the selected sites monitored for two years. The elevation range was quite wide, from 1950 to $2634 \mathrm{~m}$ a.s.l., while the catchment area ranged from 6.7 to $895 \mathrm{ha}$. On the contrary, mean slopes varied only slightly from $22^{\circ}$ to $35^{\circ}$, with an overall mean equal to $30^{\circ}$, which indicates that most of the sites were located on relatively steep slopes. The overall average soil cover percentage was $21.7 \%$, and $90 \%$ of the sites had values ranging from $2.6 \%$ to $35.4 \%$. In catchments with low soil coverage, rock debris (talus)/bedrock (R1) comprised the majority of the catchment area. The predominant land cover category was the herbaceous vegetation colonizing rock debris (N3) typical of tundra environment. Only in some sites, located at lower elevation (e.g. P31 site), other vegetation habitats, such as shrub vegetation (N8) and meadow vegetation $(\mathrm{P} 4)$, occupied substantial portions of the catchments.

Some catchment characteristics were highly correlated (Table 3) and may identify habitats that have common physical features. Mean elevation and slope were positively 
Table 2. Physical features and estimate of $\mathrm{NO}_{3}$ retention (\%) of study sites. R1, N3 and Veg. soil are expressed as percentage of the catchment area.

\begin{tabular}{lrrrrrrrrr}
\hline Site & $\begin{array}{r}\text { Site } \\
\text { Elevation } \\
\text { (m a.s.1.) }\end{array}$ & $\begin{array}{r}\text { Mean } \\
\text { Elevation } \\
\text { (ma.s.1.) }\end{array}$ & $\begin{array}{r}\text { Area } \\
(\text { ha) }\end{array}$ & $\begin{array}{r}\text { Slope } \\
(\text { deg })\end{array}$ & $\begin{array}{r}\text { Aspect } \\
(\text { deg })\end{array}$ & $\begin{array}{r}\text { R1 } \\
(\%)\end{array}$ & $\begin{array}{r}\text { N3 } \\
(\%)\end{array}$ & $\begin{array}{r}\text { Veg. soil } \\
(\%)\end{array}$ & $\begin{array}{r}\mathrm{NO}_{3} \\
\text { retention } \\
(\%)\end{array}$ \\
\hline F13 & 2634 & 2773 & 23.8 & 29.87 & 168.4 & 95.1 & 4.7 & 4.7 & 37.2 \\
F14 & 2608 & 2754 & 27.7 & 29.49 & 166.1 & 90.1 & 9.7 & 9.7 & 46.4 \\
N22 & 2555 & 2633 & 6.7 & 30.81 & 173.7 & 86.8 & 13.2 & 13.2 & 28.3 \\
H1 & 2542 & 2788 & 19.7 & 32.68 & 136.5 & 99.9 & 0.1 & 0.1 & 0.0 \\
H2 & 2520 & 2773 & 21.2 & 31.44 & 136.0 & 97.4 & 2.6 & 2.6 & 7.1 \\
H3 & 2519 & 2773 & 21.2 & 31.44 & 136.0 & 97.4 & 2.6 & 2.6 & 14.3 \\
H30 & 2385 & 2777 & 71.4 & 28.66 & 160.6 & 86.4 & 8.7 & 11.1 & 17.7 \\
MS1 & 2350 & 2805 & 114.2 & 31.13 & 182.2 & 79.6 & 13.7 & 17.5 & 33.5 \\
G9 & 2275 & 2718 & 51.4 & 29.26 & 141.9 & 79.0 & 21.0 & 21.0 & 80.0 \\
G10 & 2272 & 2718 & 51.4 & 29.26 & 141.9 & 79.0 & 21.0 & 21.0 & 47.0 \\
G11 & 2252 & 2702 & 53.8 & 28.88 & 142.7 & 75.5 & 24.3 & 24.5 & 57.5 \\
G12 & 2223 & 2653 & 118.3 & 27.90 & 147.1 & 66.8 & 32.1 & 33.1 & 68.9 \\
P31 & 2134 & 2236 & 7.6 & 21.63 & 148.0 & 0.0 & 53.1 & 100.0 & 95.0 \\
MS2 & 2000 & 2594 & 895.4 & 30.32 & 196.1 & 61.7 & 19.9 & 35.9 & 19.7 \\
T5 & 1953 & 2477 & 203.0 & 35.07 & 264.1 & 61.7 & 20.2 & 35.0 & 25.4 \\
T3 & 1951 & 2694 & 121.4 & 31.02 & 210.9 & 73.2 & 10.2 & 19.3 & 1.2 \\
\hline
\end{tabular}

Table 3. Summary of Pearson product-moment correlations among catchment landscape features.

\begin{tabular}{|c|c|c|c|c|c|c|c|}
\hline & Area & Slope & Aspect & $\begin{array}{r}\text { Mean } \\
\text { elevation }\end{array}$ & $\begin{array}{r}\text { Site } \\
\text { elevation }\end{array}$ & $\mathrm{R} 1 \%$ & N3\% \\
\hline Slope & $0.138^{\mathrm{d}}$ & & & & & & \\
\hline Aspect & $0.414^{\mathrm{d}}$ & $0.459^{\mathrm{d}}$ & & & & & \\
\hline Mean elevation & $-0.180^{\mathrm{d}}$ & $0.506^{\mathrm{a}}$ & $-0.304^{\mathrm{d}}$ & & & & \\
\hline Site elevation & $-0.530^{\mathrm{a}}$ & $0.070^{\mathrm{d}}$ & $-0.576^{\mathrm{a}}$ & $0.569^{\mathrm{a}}$ & & & \\
\hline $\mathrm{R} 1 \%$ & $-0.201^{\mathrm{d}}$ & $0.681^{b}$ & $-0.193^{\mathrm{d}}$ & $0.928^{\mathrm{c}}$ & $0.639^{\mathrm{b}}$ & & \\
\hline $\mathrm{N} 3 \%$ & $0.105^{\mathrm{d}}$ & $-0.737^{\mathrm{b}}$ & $0.013^{\mathrm{d}}$ & $-0.828^{\mathrm{c}}$ & $-0.556^{\mathrm{a}}$ & $-0.923^{c}$ & \\
\hline Veg. Soil \% & $0.185^{\mathrm{d}}$ & $-0.705^{\mathrm{b}}$ & $0.139^{d}$ & $-0.931^{\mathrm{c}}$ & $-0.597^{\mathrm{a}}$ & $-0.996^{\mathrm{c}}$ & $0.942^{\mathrm{c}}$ \\
\hline
\end{tabular}

correlated with each other and with R1 percentage. Conversely, they were negatively correlated with the fractional amount of N3 in the catchments. This indicates that talus and bedrocks are mostly located at higher altitudes on steep slopes. The vegetated soil (Veg. soil) percentage, obtained from the sum of N3, N8 and P4, was negatively correlated with mean slope, suggesting that steeper basins contained lower amounts of developed soil. Since R1 and N3 represent the main habitats in the studied basin, they are also negatively correlated to each other. On the other hand, N3, which is the most representative vegetated habitat, is strongly correlated with Veg.soil percentage.

\subsection{Chemistry of running waters}

As shown in Table 4 the ionic content of the analysed waters was very low, with electrical conductivity values ranging from 4.5 to $19 \mu \mathrm{S} \mathrm{cm}^{-1}$. The predominant ionic species were
$\mathrm{HCO}_{3}$ and $\mathrm{Ca}$, both significantly related with conductivity as expressed by correlation coefficients of $0.78(p<0.001)$ and $0.95(p<0.001)$, respectively. The values of alkalinity, ranging from 2 to $104 \mu \mathrm{eq} \mathrm{L}^{-1}$, indicate that the surface waters are very sensitive to acidification. On a molar basis, the abundance of major cations followed the order $\mathrm{Ca}>\mathrm{Na}>\mathrm{K}>\mathrm{Mg}$. The mean $\mathrm{Ca}: \mathrm{Na}$ ratio (2.2) was much higher than the ratios available in literature for the plagioclase, which is the main constituent of granodiorite (Mast et al., 1990). As reported for other catchments underlined by granitic rocks, the weathering of calcite greatly contributes cations to the waters as a result of its chemical reactivity and high rate of physical erosion in alpine environments (Mast et al., 1990).

$\mathrm{NO}_{3}$ was the principal $\mathrm{N}$ species in running waters with a mean concentration equal to $17.6 \mu \mathrm{eq} \mathrm{L}^{-1}$, while ammonia $\left(\mathrm{NH}_{4}\right)$ was close to the detection limit. The mean concentration of DON was $2 \mu \mathrm{mol} \mathrm{L}{ }^{-1}$, one order of magnitude lower 

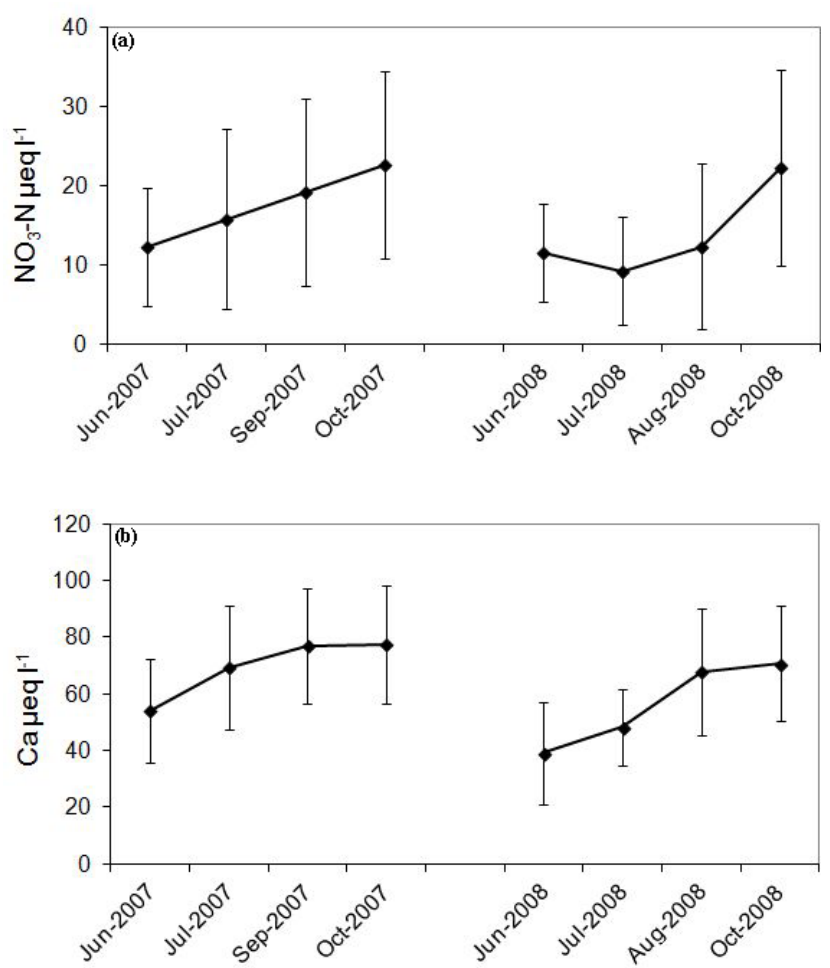

Fig. 3. Mean and standard deviation of $\mathrm{NO}_{3}$ (a) and $\mathrm{Ca}$ (b) concentrations measured in the running waters during the study period.

than inorganic $\mathrm{N}$ content. Contrary to $\mathrm{NH}_{4}$, the values of $\mathrm{NO}_{3}$ were quite variable, ranging from the detection limit to $45 \mu \mathrm{eq} \mathrm{L}^{-1}$. For comparison, $\mathrm{NO}_{3}$ concentrations measured in rainfall and snow, in 2008 at Bagni di Masino, were 18.4 and $8.1 \mu \mathrm{eq} \mathrm{L}^{-1}$, respectively (Balestrini et al., 2009). Correlation analysis revealed that the principal chemical constituents were not very good predictors of changes in the concentrations of $\mathrm{N}$ species. $\mathrm{H}^{+}$concentrations and $\mathrm{Ca}: \mathrm{Na}$ ratios were positively correlated with $\mathrm{NO}_{3}(p<0.001)$, but with low correlation coefficients $(r=0.43$ and $r=0.39$, respectively). This suggests an input from carbonate mineral weathering, in some cases, associated to nitrate leaching. DOC concentrations were negatively correlated with $\mathrm{NO}_{3}$ $(p<0.001, r=-0.38)$.

$\mathrm{NO}_{3}$ concentrations, in most of the sites, exhibited a temporal trend characterised by minimum levels in the middle of summer and a marked increase during October (Fig. 3). Other ion species such as $\mathrm{Ca}$ (Fig. 3) and $\mathrm{SO}_{4}$ showed an increasing trend starting from June/July, while $\mathrm{Cl}$, a conservative species, remained stable during the whole period. DOC concentrations did not show any trend during 2007, while higher values were measured in 2008 , with maximum values occurring in July.

In Table 2, the estimate of the biological retention of $\mathrm{NO}_{3}$, as result of both in-stream and soil retention processes, is shown for every study site. Figure 4 gives an example of the results obtained, in a case where $\mathrm{NO}_{3}$ retention was about
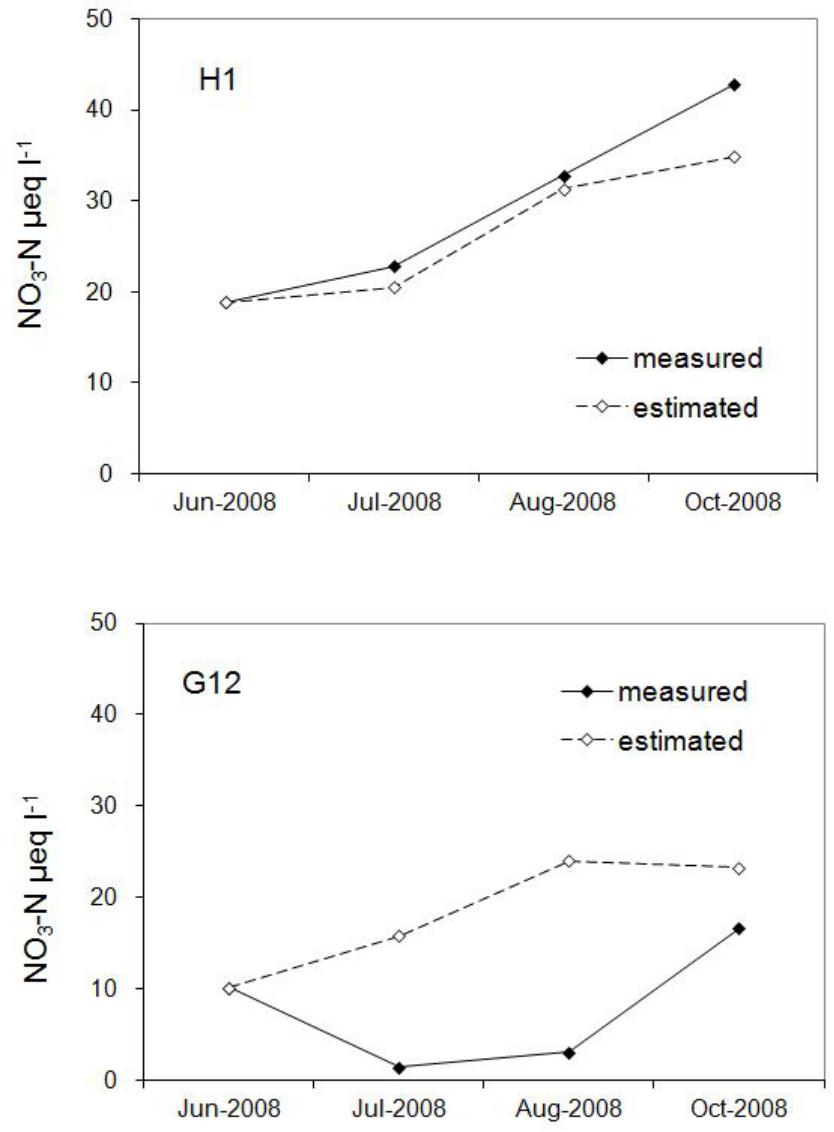

Fig. 4. Measured and estimated (without biological retention) $\mathrm{NO}_{3}$ concentrations at H1 and G12 sites from June to October 2008.

$70 \%$ (site G12) and another where there was no biological consumption (H1). The estimated retention values were homogeneously distributed, varying from 0 to $100 \%$ with a mean of $36 \%$, and they were significantly and linearly related to the mean concentration of DOC measured in 2007 $(p<0.0001, r=0.80)$.

\subsection{Correlation and regression analysis between landscape patterns and solutes}

We analysed patterns in correlations between specific groups of solutes $\left(\mathrm{NO}_{3}\right.$, DOC and $\left.\mathrm{Ca}\right)$ and groups of landscape characteristics (Table 5). Since $\mathrm{NO}_{3}$ and $\mathrm{Ca}$ exhibited monthly variations, minimum, maximum and mean values were used in the correlations. For DOC, we treated 2007 and 2008 values separately because of the significant differences between the two years.

The analysis showed that the percentages of Veg. Soil and $\mathrm{N} 3$ were strongly negatively related to $\mathrm{NO}_{3}$ concentrations. The highest correlation coefficient was found by considering the maximum concentrations mostly coincident with the values measured in October. Conversely R $1 \%$ was positively correlated to $\mathrm{NO}_{3}$. Nitrate was also significantly correlated 
Table 4. Mean \pm standard deviation of $\mathrm{pH}$ and concentrations $(\mu \mathrm{mol} \mathrm{L}-1)$ of the major chemical species measured at 16 sites during 2007 and 2008.

\begin{tabular}{llcll}
\hline & & $\mathrm{N}$ & Mean $\pm \mathrm{SD}$ & Min \\
\hline $\mathrm{pH}$ & & 112 & $6.67 \pm 0.45$ & 5.57 \\
Alkalinity & $\mu \mathrm{eq} \mathrm{L}^{-1}$ & 112 & $44.4 \pm 26.7$ & 2 \\
$\mathrm{NO}_{3}$ & $\mu \mathrm{eq} \mathrm{L}^{-1}$ & 113 & $17.6 \pm 10.8$ & $<\mathrm{DL}$ \\
$\mathrm{NH}_{4}$ & $\mu \mathrm{eqL} \mathrm{L}^{-1}$ & 113 & $0.55 \pm 0.88$ & $<\mathrm{DL}$ \\
$\mathrm{SO}_{4}$ & $\mu \mathrm{eqL} \mathrm{L}^{-1}$ & 112 & $21.6 \pm 7.4$ & 8.4 \\
$\mathrm{Cl}$ & $\mu \mathrm{eqL} \mathrm{L}^{-1}$ & 111 & $3.9 \pm 3.5$ & 0.5 \\
$\mathrm{Ca}$ & $\mu \mathrm{eqL} \mathrm{L}^{-1}$ & 112 & $63 \pm 24.4$ & 22.4 \\
$\mathrm{Mg}$ & $\mu \mathrm{eq} \mathrm{L} \mathrm{L}^{-1}$ & 112 & $5.2 \pm 2.0$ & 1.6 \\
$\mathrm{Na}$ & $\mu \mathrm{eqL} \mathrm{L}^{-1}$ & 111 & $13.9 \pm 5.2$ & 5.1 \\
$\mathrm{~K}$ & $\mu \mathrm{eq} \mathrm{L} \mathrm{L}^{-1}$ & 113 & $7.3 \pm 2.7$ & 3.1 \\
$\mathrm{DON}$ & $\mu \mathrm{mol} \mathrm{L}^{-1}$ & 112 & $1.8 \pm 2.7$ & $<\mathrm{D} . \mathrm{L}$ \\
$\mathrm{DOC}$ & $\mu \mathrm{mol} \mathrm{L}^{-1}$ & 113 & $95 \pm 39$ & 31 \\
\hline
\end{tabular}

with the mean slope and elevation of the basins. Similarly to $\mathrm{NO}_{3}$ but with an opposite behaviour, DOC measured during 2007 was positively correlated with soil cover and N3\%, and negatively correlated with $\mathrm{R} 1 \%$ and the mean slope. As for DOC, the percentage of $\mathrm{NO}_{3}$ retention was strongly positively correlated with soil cover and $\mathrm{N} 3 \%$, and negatively with R1\%, mean slope and, with a weaker significance, to the mean elevation. Soil cover did not influence Ca concentrations in surface waters, but a highly significant correlation was found between $\mathrm{Ca}$ and the mean aspect of the basins (Table 5). The correlation between $\mathrm{Ca}$ and mean elevation was less significant.

It is worth noting that minimum values of both $\mathrm{NO}_{3}$ and Ca concentrations were mainly observed at the end of June, when the snowmelt had a dilution effect on surface waters. This could explain the lower significance of some correlations between the concentrations of some chemical species and the physical features of the basins, as the melting waters modified the hydrological connection between substrates and surface waters.

The linear model using the N3\% was a good predictor for $\mathrm{NO}_{3}$ concentrations in the surface waters; $85 \%$ of the variation in maximum $\mathrm{NO}_{3}$ values was explained by this linear equation (Fig. 6). An exponential model better described the relationship between maximum $\mathrm{NO}_{3}$ and $\mathrm{R} 1 \%$, explaining almost $89 \%$ of $\mathrm{NO}_{3}$ variation. The same model, using vegetated soil cover, was also a very good predictor of both peak $\mathrm{NO}_{3}\left(R^{2}=0.899\right)$ and mean $\mathrm{NO}_{3}$ concentrations $\left(R^{2}=0.803\right)$ in the studied sites. The exponential models using mean elevation and slope were slightly less predictable (67 and $78 \%$, respectively) compared to soil use (Figs. 5 and 6). $\mathrm{NO}_{3}$ retention declined linearly with decreasing $\mathrm{N} 3 \%$ and this linear model explained about $70 \%$ of the variation in $\mathrm{NO}_{3}$ retention (\%) (Fig. 7).
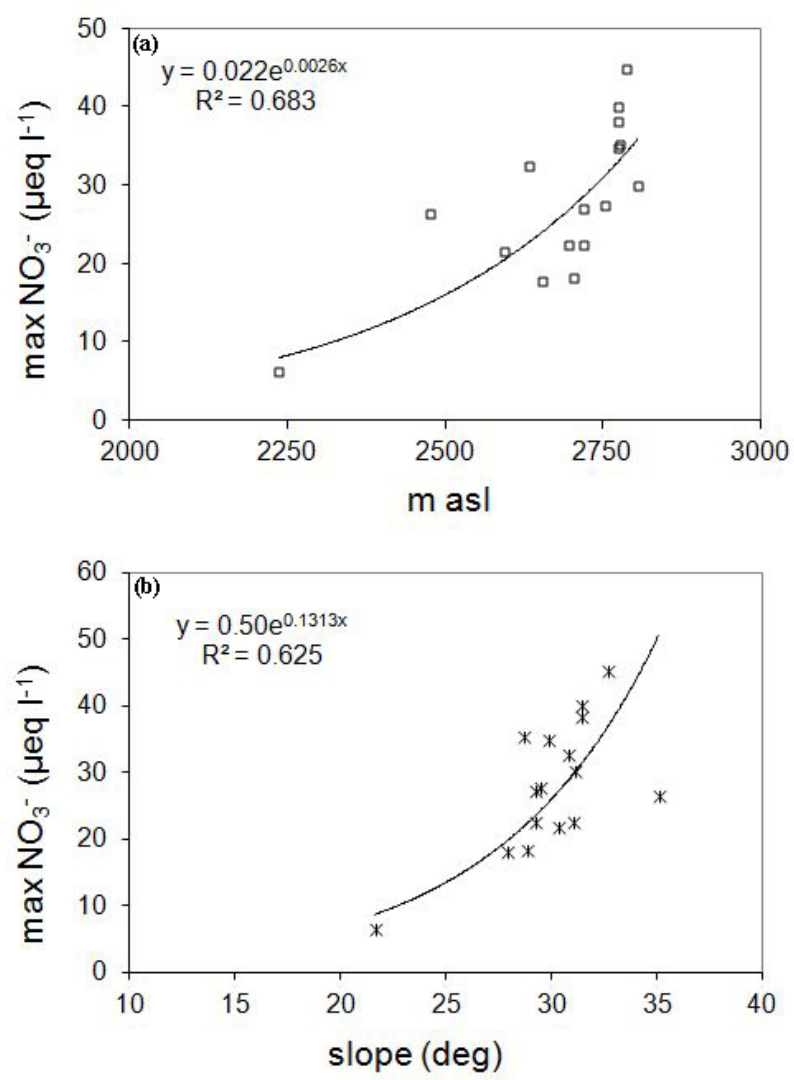

Fig. 5. Relationship between the maximum NO3 concentration in catchment outflow and (a) elevation, (b) slope, for high-elevation watersheds of the Val Masino.

\section{Discussion}

The range of $\mathrm{NO}_{3}$ concentrations in the higher Val Masino is consistent with the data reported for a glacial valley in the Swiss Alps (Tockner et al., 2002) and for 73 high-elevation lakes of the eastern Alps in Austria (Psenner, 1989). Higher $\mathrm{NO}_{3}$ values $\left(26 \mu \mathrm{eq} \mathrm{L}^{-1}\right.$, as median) were reported for alpine lakes in the Tatra Mountains (Kopaceck et al., 2005), while slightly lower $\mathrm{NO}_{3}$ concentrations (about $12 \mu \mathrm{eq} \mathrm{L}{ }^{-1}$ ) were measured in an Italian Alpine valley (Stelvio National Park), at 1950-3768 ma.s.l., located about $100 \mathrm{~km}$ east from Val Masino (Boscaini et al., 2003). The comparison with highelevation ecosystems in the United States reveals that our data are similar to the mean values $\left(16-24 \mu \mathrm{eq} \mathrm{L}^{-1}\right)$ reported for some Rocky Mountain sites (Campbell et al., 1995; Baron and Campbell, 1997), but greater than for Sierra Nevada sites (mean of $5.4 \mu \mathrm{eq} \mathrm{L} \mathrm{L}^{-1}$ ) (Sickman et al., 2002).

$\mathrm{NO}_{3}$ was the dominant $\mathrm{N}$ form in the analysed waters since $\mathrm{NH}_{4}$ and organic $\mathrm{N}$, on average, contributed only 3 and $10 \%$ of total $\mathrm{N}$, respectively. Both species occurred at concentrations often close to the detection limits, and did not show any significant correlation with the physical features analysed in the present study. Comparable concentrations and 
Table 5. Summary of Pearson product-moment correlations between some catchment features and concentration of some chemical species and $\mathrm{NO}_{3}$ retention $(\%)$.

\begin{tabular}{|c|c|c|c|c|c|c|c|c|c|}
\hline & $\begin{array}{r}\mathrm{Ca} \\
\mathrm{Max}\end{array}$ & $\begin{array}{r}\mathrm{Ca} \\
\mathrm{Min}\end{array}$ & $\begin{array}{r}\mathrm{Ca} \\
\text { Mean }\end{array}$ & $\begin{array}{l}\mathrm{NO}_{3} \\
\mathrm{Max}\end{array}$ & $\begin{array}{r}\mathrm{NO}_{3} \\
\mathrm{Min}\end{array}$ & $\begin{array}{r}\mathrm{NO}_{3} \\
\text { Mean }\end{array}$ & $\begin{array}{l}\text { DOC } \\
2008\end{array}$ & $\begin{array}{l}\text { DOC } \\
2007\end{array}$ & $\begin{array}{r}\% \mathrm{NO}_{3} \\
\text { Retention }\end{array}$ \\
\hline Area & $0.313^{\mathrm{d}}$ & $0.307^{\mathrm{d}}$ & $0.358^{d}$ & $-0.219^{\mathrm{d}}$ & $-0.022^{\mathrm{d}}$ & $-0.104^{\mathrm{d}}$ & $-0.033^{\mathrm{d}}$ & $-0.114^{\mathrm{d}}$ & $-0.060^{\mathrm{d}}$ \\
\hline Mean slope & $0.221^{\mathrm{d}}$ & $0.029^{\mathrm{d}}$ & $0.185^{\mathrm{d}}$ & $0.669^{\mathrm{b}}$ & $0.511^{\mathrm{a}}$ & $0.724^{b}$ & $-0.454^{\mathrm{d}}$ & $-0.569^{\mathrm{a}}$ & $-0.754^{b}$ \\
\hline Mean aspect & $0.830^{\mathrm{c}}$ & $0.510^{\mathrm{a}}$ & $0.789^{c}$ & $-0.147^{\mathrm{d}}$ & $-0.177^{\mathrm{d}}$ & $-0.022^{\mathrm{d}}$ & $-0.226^{\mathrm{d}}$ & $-0.254^{\mathrm{d}}$ & $-0.263^{\mathrm{d}}$ \\
\hline Mean elevation & $-0.457^{\mathrm{d}}$ & $-0.632^{b}$ & $-0.608^{\mathrm{a}}$ & $0.722^{b}$ & $0.510^{\mathrm{a}}$ & $0.575^{\mathrm{a}}$ & $-0.123^{\mathrm{d}}$ & $-0.432^{\mathrm{d}}$ & $-0.554^{\mathrm{a}}$ \\
\hline Site elevation & $-0.342^{\mathrm{d}}$ & $-0.296^{\mathrm{d}}$ & $-0.414^{\mathrm{d}}$ & $0.664^{\mathrm{b}}$ & $0.473^{\mathrm{d}}$ & $0.493^{\mathrm{d}}$ & $0.139^{d}$ & $-0.368^{\mathrm{d}}$ & $-0.194^{\mathrm{d}}$ \\
\hline $\mathrm{R} 1 \%$ & $-0.276^{\mathrm{d}}$ & $-0.418^{\mathrm{d}}$ & $-0.391^{\mathrm{d}}$ & $0.855^{\mathrm{c}}$ & $0.619^{\mathrm{a}}$ & $0.733^{b}$ & $-0.285^{\mathrm{d}}$ & $-0.561^{\mathrm{a}}$ & $-0.642^{b}$ \\
\hline $\mathrm{N} 3 \%$ & $0.137^{\mathrm{d}}$ & $0.301^{\mathrm{d}}$ & $0.277^{\mathrm{d}}$ & $-0.918^{\mathrm{c}}$ & $-0.754^{\mathrm{b}}$ & $-0.836^{\mathrm{c}}$ & $0.287^{\mathrm{d}}$ & $0.720^{\mathrm{b}}$ & $0.835^{\mathrm{c}}$ \\
\hline Soil cover $\%$ & $0.245^{\mathrm{d}}$ & $0.410^{\mathrm{d}}$ & $0.374^{\mathrm{d}}$ & $-0.854^{\mathrm{c}}$ & $-0.628^{b}$ & $-0.740^{\mathrm{b}}$ & $0.299^{\mathrm{d}}$ & $0.589^{\mathrm{a}}$ & $0.688^{b}$ \\
\hline
\end{tabular}

${ }^{\mathrm{a}}=$ significant correlations $p<0.05,{ }^{\mathrm{b}}=$ significant correlations $p<0.01,{ }^{\mathrm{c}}=$ significant correlations $p<0.001,{ }^{\mathrm{d}}=$ not significant correlations.

percentages of DON have been reported for alpine watersheds in the Colorado Front Range (Hood et al., 2003). In their study, Hood et al. (2003) also reported an increase in DON moving downstream towards the forested portion of the catchment where DON contribution to total $\mathrm{N}$ reached $45 \%$. Differently, at the high-elevation Emerald Lake watershed in the Sierra Nevada, organic $\mathrm{N}$ was the major form of $\mathrm{N}$ exports to stream water (Williams et al., 2001). Organic $\mathrm{N}$ is not commonly measured in remote ecosystems and its role in $\mathrm{N}$ cycling at high-elevation systems is still unknown. We could not exclude that the analytical constrains were at the basis of the lack of relationship between DON and the percentage of vegetated soil or N3, but we are more likely to think that organic $\mathrm{N}$ represents a "leak" of $\mathrm{N}$ from terrestrial to aquatic ecosystems. Some authors introduced the hypothesis called "leaky faucet", according to which there is a persistent "leak" of DON from terrestrial catchments due to the DON decoupling from biological demand for N (Aber et al., 1998). Accordingly to Williams et al. (2001), our results suggest that the "leaky faucet hypothesis" could also be appropriate in explaining DON behaviour in temperate ecosystems above the treeline where talus and tundra areas are predominant. In contrast to $\mathrm{DON}, \mathrm{NO}_{3}$ in running waters showed a spatial pattern strictly connected to the abundance of different land cover categories within the basin, each characterized by specific and common physical features. Our results clearly demonstrate that in an ecosystem characterized by reduced habitat diversification and homogenous geology, the relative proportions of the two main environmental types, talus (R1) and tundra vegetation (N3), become powerful predictors of $\mathrm{NO}_{3}$ concentrations in surface waters. Other indices related to catchment topography, such as slope and elevation, are both useful to predict $\mathrm{NO}_{3}$ concentrations, but the obtained relationships were partially due to the covariance of slope and elevation with R1 and N3. The substantial feature that distinguishes these two environments is soil cover. N3 includes the fraction of the basin covered with vegetated soil while, with the exception of some patches of fine particles within the boulder matrix, soil is largely absent in talus fields (R1). $\mathrm{NO}_{3}$ exports to stream water diminished with increasing size of the vegetated soil fraction within each catchment. The presence of soil is the strongest discriminating factor in determining the possibility of $\mathrm{NO}_{3}$ retention. This means that the biological community, represented by microorganisms and plants living in soils, is efficient in consuming $\mathrm{N}$ available in the water matrix despite the adverse environmental conditions, such as low temperature, short growing season, extensive and deep snow cover (Schmidt et al., 1999; Freppaz et al., 2007). The biological nature of $\mathrm{N}$ consuming processes is also supported by the estimate of $\mathrm{N}$ retention that declined linearly with decreasing N3 percentage.

The area of the basins, which can represent a proxy for hydrological flowpath because it takes into account the time and distance from the source, did not significantly explain $\mathrm{NO}_{3}$ variability. The relationship between discharge and some chemical species was analysed in Balestrini et al. (2006) for the Masino stream at the closing section of the basin (Bagni di Masino). There was an inverse, highly significant correlation between flow and $\mathrm{SO}_{4}, \mathrm{Ca}, \mathrm{Mg}, \mathrm{K}$, and $\mathrm{Na}$ concentrations, indicating the importance of the dilution process in controlling the variability of these solutes. Conversely, the hydrological regime did not significantly explain the variations in $\mathrm{NO}_{3}$ suggesting that other factors apart from discharge controlled the temporal trends of inorganic $\mathrm{N}$ in Masino stream water.

In recent years, several studies have investigated the relationships between surface water $\mathrm{N}$ and physical features of the catchments, but few of them focused on ecosystems above the treeline. Lovett et al. (2000) reported that $\mathrm{NO}_{3}$ concentrations of 39 streams in a forested catchment (750 $1250 \mathrm{~m}$ ) in the Catskill Mountains (NY) was poorly correlated with some physical features (e.g slope, relief, watershed area) that could influence hydrologic residence time. The same authors hypothesized that the key factor able to produce variations in stream $\mathrm{NO}_{3}$ contents had to be found in forest species composition induced by land use practices 

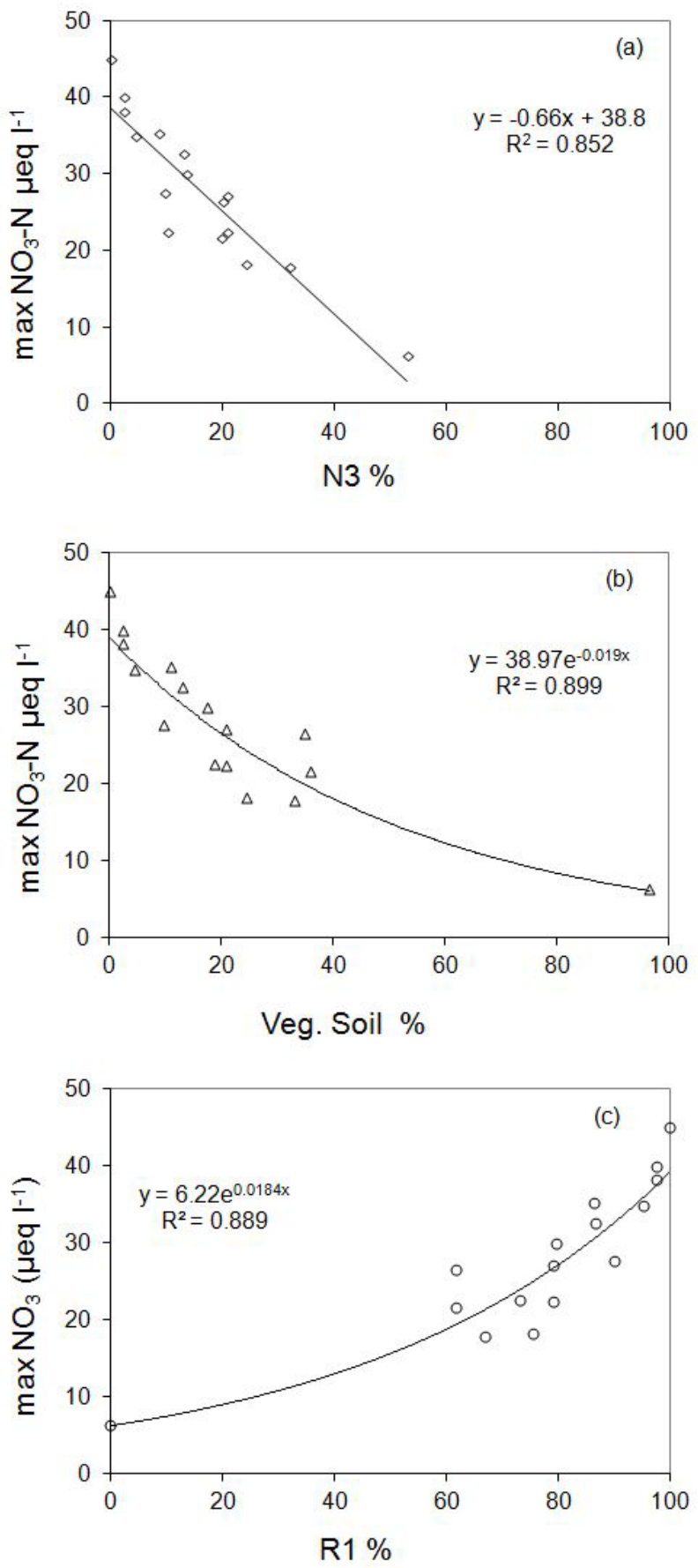

Fig. 6. Relationship between the maximum $\mathrm{NO}_{3}$ concentration in catchment outflow and (a) tundra (N3) percentage (b) vegetated soil percentage and (c) talus and bedrock (R1) percentage, for highelevation watersheds of the Val Masino.

in the past. The relation between $\mathrm{N}$ yield and simple catchment features such as area, elevation and runoff was investigated by Lewis (2002) in 19 minimally disturbed watersheds spread all over the United States, and mostly located below the treeline. Statistical analysis showed that elevation

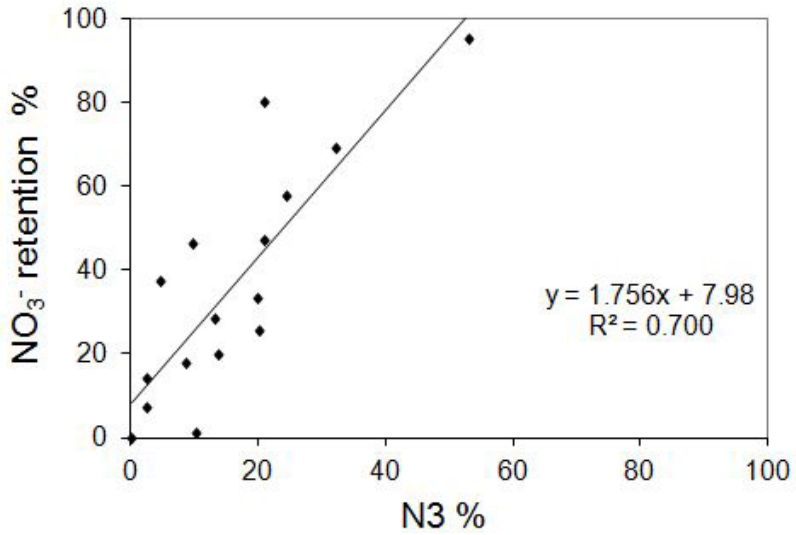

Fig. 7. Relationship between $\mathrm{NO}_{3}$ retention in catchment outflow and tundra $(\mathrm{N})$ percentage, for high-elevation watersheds of the Val Masino.

and watershed area bear no significant relationship to $\mathrm{N}$ yield for these watersheds. Only runoff was strongly related to the yields of total $\mathrm{N}$ and $\mathrm{N}$ fractions.

Clow and Sueker (2000) analysed the relation between stream water chemistry and topographic, vegetative, and geologic characteristics of nine alpine/subalpine basins in the Rocky Mountain National Park, Colorado. Similarly to the results of the present study, $\mathrm{NO}_{3}$ concentrations were positively correlated with steep slopes, unvegetated terrain and young debris, and was negatively correlated with subalpine meadow vegetation. On the other hand, differently to our findings, they did not find any significant correlation between solute concentrations and the percentage of each basin covered by tundra plant species. Based on these data, the authors developed some regression models able to explain most variation in $\mathrm{NO}_{3}$ chemistry of these nine catchments. However, the same models tested with existing synoptic streamsurvey data from the Rocky Mountains revealed a poor performance. The authors explained this with a high proportion of small, high-elevation catchments with limited areas of subalpine soils comprised in the original data set, compared to the calibration data. These findings, along with those obtained in the present study, suggest that the modelling approach will only be really successful when applied on homogenous data sets, since both abiotic and biotic processes could influence $\mathrm{N}$ in water bodies located in different bioclimatic zones (e.g. alpine versus montane zones) in different ways, and this could limit the overall suitability of simple regression models.

Sickman et al. (2002) found that soil cover and elevation were good predictors of stream $\mathrm{NO}_{3}$ concentrations and dissolved inorganic nitrogen (DIN) retention in alpine and subalpine ecosystems in both the Sierra Nevada and Rocky Mountains. Particularly, in both mountain ranges, the annual volume-weighted mean $\mathrm{NO}_{3}$ concentrations decreased in a logarithmic fashion as soil cover increased. Similarly, $\mathrm{NO}_{3}$ 


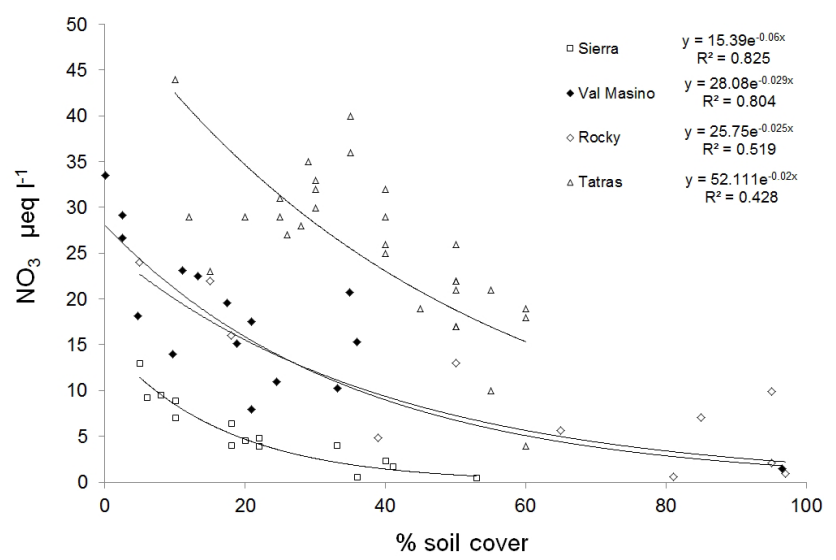

Fig. 8. Relationship between the mean $\mathrm{NO}_{3}$ concentration in catchment outflow and soil cover for high-elevation watersheds of the Val Masino (present study), the Sierra Nevada, the Rocky Mountains and the Tatra Mountains (from Sickman et al., 2002, and Kopacek et al., 2005).

concentrations measured in alpine lakes in the Tatras Mountains (Slovakia-Poland) correlated negatively with parameters characterising land cover in the catchments, i.e. percent land cover with meadow, soil depth and soil pool (Kopacek et al., 2005).

In Fig. 8 we compared our data of $\mathrm{NO}_{3}$ concentrations and land cover percentage to those reported by Sickman et al. (2002) and Kopacek et al. (2005). This comparison revealed that the proportion of soil extension within the catchments exerted an analogous effect on $\mathrm{NO}_{3}$ concentrations across the alpine regions of Italy and both Poland and western United States. The exponential coefficient of the Sierra Nevada equation was about 2, 2.4 and 3-fold greater than the coefficients of the Masino Valley, Rocky Mountains and Tatra Mountains equations, respectively. This suggests that the Sierra Nevada soils are more efficient in retaining $\mathrm{NO}_{3}$, possibly because of differences in physical (e.g. soil climate) and chemical (e.g. organic C) soil properties (Sickman et al., 2002) compared to the other three areas. On the other hand, the equation intercepts that decreased in the order Tatra Mountains $\gg$ Masino valley $>$ Rocky Mountains $\gg$ Sierra Nevada, may reflect different $\mathrm{N}$ atmospheric inputs. The annual mean wet deposition flux of inorganic $N$ (for the period 1995-2010) was $10.5 \mathrm{~kg} \mathrm{ha}^{-1} \mathrm{yr}^{-1}$ at the closing section of the basin at Bagni di Masino (1190 ma.s.1.). The inorganic $\mathrm{N}$ pool stored in snowpack was measured in spring 2008, between $1950 \mathrm{~m}$ and $2250 \mathrm{~m}$ a.s.1., within the Masino catchment (Balestrini et al., 2009). The resulting mean $\mathrm{N}$ load of $1.08 \mathrm{~kg} \mathrm{ha}^{-1}$ for the full length of the snow period (November 2007-May 2008) accounted for $40 \%$ of the load measured at Bagni di Masino. Such percentage was used to estimate the total DIN loading for the most elevated part of the catchment. This estimate $\left(4.2 \mathrm{~kg} \mathrm{ha}^{-1} \mathrm{yr}^{-1}\right)$, together with the deposition rates of the Sierra Nevada $\left(1.8 \mathrm{~kg} \mathrm{ha}^{-1} \mathrm{yr}^{-1}\right)$, Rocky Mountains (3.6 $\mathrm{kg} \mathrm{ha}^{-1} \mathrm{yr}^{-1}$ ) and Tatra Mountains $\left(8.5 \mathrm{~kg} \mathrm{ha}^{-1} \mathrm{yr}^{-1}\right.$ ), have been plotted (Fig. 9) against the intercepts of the equations reported in Fig. 8. It is apparent that the relationship between the two variables is appropriately accounted for by a linear model. These observations are comparable to the MAGIC model (Model of Acidification of Groundwater in Catchments) predictions in which simulated $\mathrm{NO}_{3}$ leaching is related to soil carbon pool by a curvilinear relationship dependent from the $\mathrm{N}$ deposition rate (Evans et al., 2006). Previous studies (e.g. Helliwell et al., 2007; Evans et al., 2006, aimed at analysing control on $\mathrm{NO}_{3}$ leaching in mountain freshwaters, reached similar conclusions about the importance of soil carbon pool in controlling $\mathrm{N}$ retention. Nonetheless, our findings suggest that in homogenous environments as those above the tree line, the percentage of soil cover may be sufficient for predicting $\mathrm{N}$ water concentrations independently of the carbon pool contents that are often rather difficult to obtain. Some authors (Hope et al., 1997) reported significant linear relationships between soil C pool and DOC export, and Evans et al. (2006) used DOC as a proxy for $\mathrm{C}$ pool in the relationships with $\mathrm{NO}_{3}$ concentrations in surface waters. In the present study the analysed relationship between DOC and $\mathrm{NO}_{3}$, as well as DOC and vegetated land cover fractions within the catchments were significant, but not as significant as that reported between $\mathrm{NO}_{3}$ and soil cover percent. Since significant differences in DOC concentrations were also found between 2007 and 2008, we hypothesized that DOC in surface waters sampled at high elevation may originate not only from the soil but also from the algae and bacteria growing in the water. For these reasons, the relationships between $\mathrm{NO}_{3}$ and DOC could be more complex with respect to soil cover percent.

A recent study by Taylor and Townsend (2010) proposed that the dissolved organic carbon to $\mathrm{NO}_{3}$ ratio $\left(\mathrm{DOC}: \mathrm{NO}_{3}\right)$ of a substrate resource (freshwater, ocean, soil) strongly influences $\mathrm{NO}_{3}$ accumulation or uptake by regulating a host of microbial processes such as nitrification and denitrification. The DOC: $\mathrm{NO}_{3}$ ratio at our sites ranged from 2.3 to 97 . A scatterplot of $\mathrm{NO}_{3}$ retention (\%) versus the $\mathrm{DOC}: \mathrm{NO}_{3}$ ratio shows that lower percentages of $\mathrm{NO}_{3}$ retention were associated with DOC : $\mathrm{NO}_{3}$ of about 2.5 (Fig. 10). This value falls below the 3.5 threshold identified by Taylor and Townsend for microbial biomass, below which an increase of $\mathrm{NO}_{3}$ in water is expected. Accordingly to our data, Williams et al. (2011) found DOC : $\mathrm{NO}_{3}$ less than 5 anchored, to high elevation stream samples characterized by high $\mathrm{NO}_{3}$ concentrations. These findings enhance the role of vegetated soil in $\mathrm{N}$ retention, as it may provide a certain amount of available organic carbon so as to avoid carbon limitation that may drive the accrual of $\mathrm{NO}_{3}$ in the system.

The fact that soils above the tree line could be effective in controlling the $\mathrm{NO}_{3}$ dynamics gives rise to some reflections on the current theories on $\mathrm{N}$ saturation, mechanisms and effects of which have been widely studied in forest ecosystems 


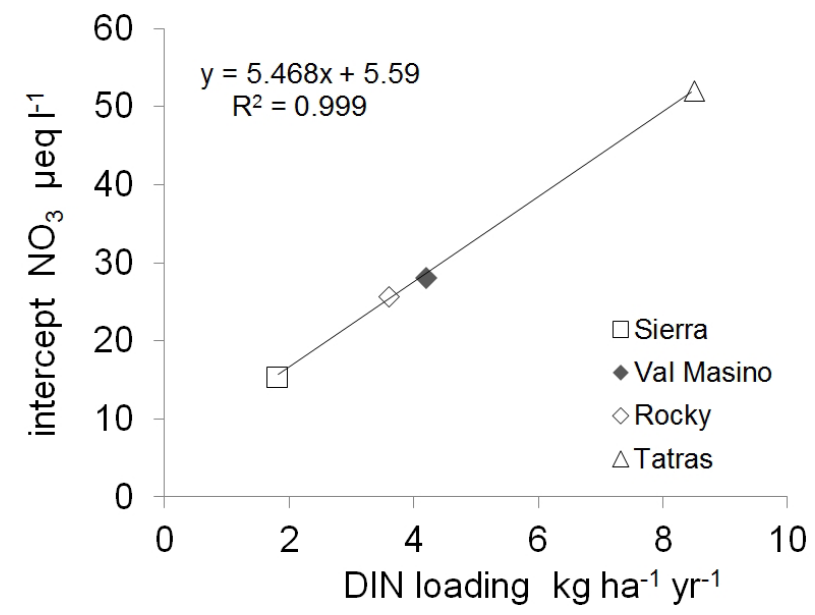

Fig. 9. Relationship between the intercepts of the equations reported in Fig. $8\left(\mathrm{NO}_{3}-\mathrm{N}\right.$ concentration expected for basins without soil cover) and DIN deposition loading measured at Val Masino (present study), the Sierra Nevada, the Rocky Mountains (Sickman et al., 2002) and the Tatra Mountains (Kopacek et al., 2005).

across the United States and Europe (Aber et al., 1998; Gundersen et al., 1998; Curtis et al., 2011). However, especially in Europe, few studies have analysed stream water $\mathrm{NO}_{3}$ signals in remote portions of high-elevation ecosystems such as Alpine tundra. The present study describes some catchments spread in a relatively small area of about 1000 ha along an elevational gradient of $700 \mathrm{~m}$ (from 1950 to $2650 \mathrm{~m}$ a.s.l.) and probably exposed to the same $\mathrm{N}$ deposition rate. Following the approach of Traaen and Stoddard (1995), the different seasonal patterns in surface water $\mathrm{NO}_{3}$ concentrations observed for the study basins, could suggest the degree of natural variability in response to a $\mathrm{N}$ loading of about $4 \mathrm{~kg} \mathrm{ha}^{-1} \mathrm{yr}^{-1}$. Some basins showing growing season $\mathrm{NO}_{3}$ concentrations near the detection limit, could be included in the stage 0 or 1 of the sequence of $\mathrm{N}$-saturation. On the contrary, summer concentrations of about $20 \mu \mathrm{eq} \mathrm{L}^{-1}$ may lead to suppose that the basins were already at stage 2-3. According to the theoretical approach proposed by Curtis et al. (2011), we think that these elevated $\mathrm{NO}_{3}$ concentrations do not necessarily imply $\mathrm{N}$ saturation in terrestrial ecosystems, but could indicate a pathway of $\mathrm{NO}_{3}$ leaching dominated by a hydrological bypass or the presence of carbon poor locations (e.g. talus slopes) not able to store $\mathrm{N}$ in the long term. On the other hand, the low $\mathrm{NO}_{3}$ output found in some other sub-basins demonstrates that soils of the high Val Masino represent carbon rich pools where retention and/or accumulation of $\mathrm{N}$ could occur in the long term. What distinguishes the forest ecosystems from the Alpine tundra is the size of the pool where $\mathrm{N}$ transformations occur, i.e. the $\%$ of developed soil, usually present in smaller extent in the catchments at high elevation than in forest areas. Therefore, the sensitivity of the environments above the tree line to $\mathrm{N}$ deposition is mainly due to the relative proportion of vegetated soil within the catchments.

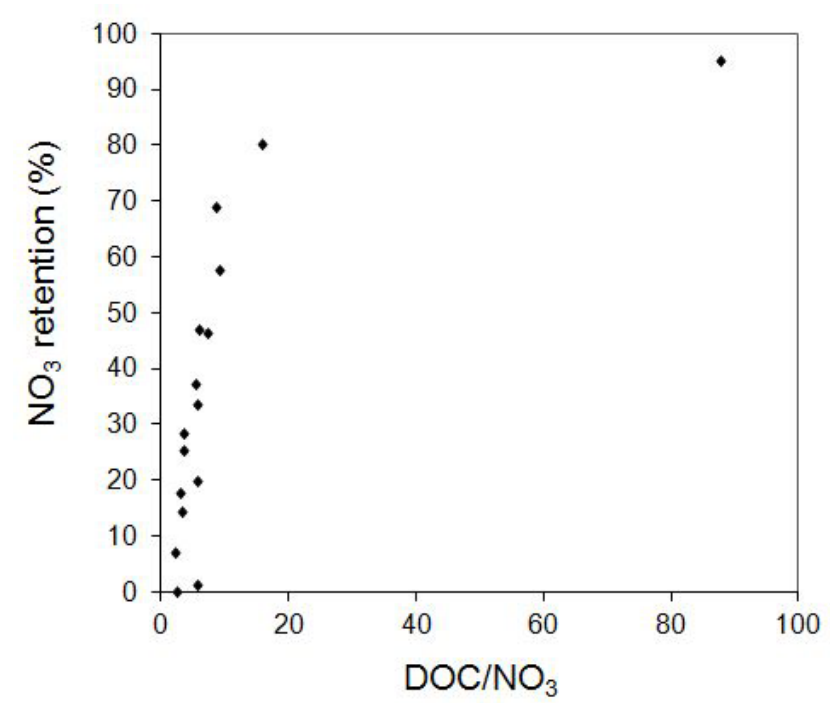

Fig. 10. Scatterplot of the percentage of $\mathrm{NO}_{3}$ retention versus the DOC : $\mathrm{NO}_{3}$ calculated using the mean concentrations measured in the stream water samples.

\section{Conclusions}

The chemical characterization of surface waters, along with the assessment of landscape features of the portion of the basin located above the tree line, added a noteworthy piece to the study of $\mathrm{N}$ dynamics in a "Long Term Environmental Research" station of the Italian Alps (Val Masino). This study revealed important and differentiated relationships between a geochemical descriptor $(\mathrm{Ca})$ and two biological active species $\left(\mathrm{NO}_{3}\right.$ and $\left.\mathrm{DOC}\right)$ with some topographic features and land cover of the basin.

From our findings, we deduced that land cover can be considered one of the most important factors affecting the water quality of streams in high elevation catchments, with a contrasting effect on $\mathrm{N}$ and $\mathrm{C}$ pools. The areal extension of developed soils is strictly related to the retention of $\mathrm{N}$, and this suggests a fundamental role of the microbial community and plants in limiting leaching losses of $\mathrm{NO}_{3}$ also in highelevation ecosystems. Therefore, any variation in land cover due to global change could significantly affect the quality of running waters. According to climate change scenarios in the alpine space, we might expect an upward shift of alpine plants and an increase in plant species richness of high alpine and nival vegetation (Walther et al., 2005; Pauli et al., 2007). Nevertheless, at high elevation, even if climatic conditions were favourable, the diffusion of tundra plant species could be limited by the low rate of soil formation, limiting the increase of the vegetated soil area (Letey et al., 2010). At the same time, changes in the characteristics of the talus areas, for example, due to permafrost degradation, could significantly affect water quality (Caine, 2010). All these changes could appreciably influence the quality of running waters 
above the tree line and would have to be considered for water resource management and planning in alpine areas.

Furthermore, the comparison of the results obtained here with those from the Tatra Mountains, Rocky Mountains and Sierra Nevada supports our overall findings, and suggests that the efficiency of soils in retaining $\mathrm{N}$ can be influenced by $\mathrm{N}$ atmospheric loading. Since the equations linking soil cover and stream $\mathrm{NO}_{3}$ concentrations could be used to quantify the effect of $\mathrm{N}$ loading on $\mathrm{N}$ exports, they may also contribute to the evaluation of critical $\mathrm{N}$ loads in alpine ecosystems.

Acknowledgements. The authors would like to thank C. A. Delconte for chemical analyses and G. Giumelli and D. Fiorini for the technical support. Funding was provided by the ERSAF (Ente Regionale per i Servizi all'Agricoltura e alle Foreste).

Edited by: A. Butturini

\section{References}

Aber J. D., McDowell, W., Nadelhoffer, K. J., Magill, A., Berntson, G., Kamakea, M., McNulty, S., Currie, W., Rustad, L., and Fernandez, I.: Nitrogen saturation in northern forest ecosystems: Hypothesis revisited, BioScience, 48, 921-934, 1998.

Balestrini, R. and Tagliaferri, A.: Atmospheric deposition and canopy exchange processes in alpine forest ecosystems (northern Italy), Atmos. Environ., 35-36, 6421-6433, 2001.

Balestrini, R., Galli, L., and Tartari, G.: Wet and dry atmospheric deposition at prealpine and alpine sites in northern Italy, Atmos. Environ., 34, 1455-1470, 2000.

Balestrini, R., Arese, C., Delconte, C. A., Lotti, A., and Salerno, F.: Nitrogen removal in subsurface water by narrow buffer strips in the intensive farming landscape of the Po River watershed, Italy, Ecol. Eng., 37, 148-157, 2001.

Balestrini, R., Tagliaferri, A., Tartari, G., and Di Girolamo, F.: Forest condition and chemical characteristics of atmospheric depositions: research and monitoring network in Lombardy (Suppl. 1), J. Limnol., 61, 117-128, 2002.

Balestrini, R., Di Martino, N., and Van Miegroet, H.: Nitrogen cycling and mass balance for a forested catchment in the Italian Alps, Biogeochemistry, 78, 97-123, 2006.

Balestrini, R., Arese, C., Delconte, C. A., Lotti, A., Passatore, L., Freppaz, M., and Filippa, G.: Nitrogen dynamic in a highelevation catchment in the Italian Alps, Geophys. Res. Abstr., EGU2009-9945, EGU General Assembly 2009, Vienna, Austria, 2009.

Balestrini, R., Arese, C., Delconte, C. A., Lotti, A., and Salerno, F.: Nitrogen removal in subsurface water by narrow buffer strips in the intensive farming landscape of the Po River watershed, Italy, Ecol. Eng., 37, 148-157, 2011.

Baron, J. S. and Campbell, D. H.: Nitrogen fluxes in a high elevation Colorado Rocky Mountain Basin, Hydrol. Process., 11, 783-799, 1997.

Boscaini, A., Corradini, F., Lencioni, V., and Maiolini, B.: Caratterizzazione morfologica e chimico-fisica di un sistema idrografico alpino (Parco Nazionale dello Stelvio, Trentino), Studi Trentini Scienze Naturali, Acta Biol., 80, 43-49, 2003.
Brooks, P. D. and Williams, M. W.: Snowpack controls on nitrogen cycling and export in seasonally snow-covered catchments, Hydrol. Process., 13, 2177-2190, 1999.

Burns, D. A.: Atmospheric nitrogen deposition in the Rocky Mountains of Colorado and southern Wyoming- a review and new analysis of past study results, Atmos. Environ., 37, 921-932, 2003.

Caine, N.: Recent hydrologic change in a Colorado alpine basin: an indicator of permafrost thaw?, Ann. Glaciol., 51, 130-134, 2010.

Campbell, D. H., Clow, D. W., Ingersoll, G. P., Mast, M. A., Spahr, N. E., and Turk, J. T.: Processes controlling the chemistry of two snowmelt-dominated streams in the Rocky Mountains, Water Resour. Res., 31, 2811-2821, 1995.

Cannone, N., Diolaiuti, G., Guglielmin, M., and Smiraglia, C.: Accelerating climate change impacts on alpine Glacier forefield ecosystems in the European Alps, Ecol. Appl., 18, 637-648, 2008.

Clow, D. W. and Sueker, J. K.: Relations between basin characteristics and stream water chemistry in alpine/subalpine basins in Rocky Mountain National Park, Colorado, Water Resour. Res., 36, 49-61, 2000.

Curtis, C., Evans, C., Goodale, C., and Heaton, T.: What have stable isotope studies revealed about the nature and mechanisms of $\mathrm{N}$ Saturation and nitrate leaching from semi-natural catchments?, Ecosystems, 14, 1021-1037, 2011.

Dise, N. B. and Wright, R. F.: Nitrogen leaching from European forests in relation to nitrogen deposition, Forest Ecol. Manage., 71, 153-161, 1995.

DUSAF 1.1: Regione Lombardia, Sistema Informativo Territoriale - Repertorio Cartografico e Banche dati Territoriali, Regione Lombardia - Territorio e Urbanistica, 2001.

Evans, C. D., Reynolds, B., Jenkins, A., Helliwell, R. C., Curtis, C. J., Goodale, C. L., Ferrier, R. C., Emmett, B. A., Pilkington, M. G., Caporn, S. J. M., Carroll, J. A., Norris, D., Davies, J., and Coull, M. C.: Evidence that soil carbon pool determines susceptibility of seminatural ecosystems to elevated nitrogen leaching, Ecosystems, 9, 453-462, 2006.

Fenn, M. E., Haeuber, R., Tonnesen, G. S., Baron, J. S., GrossmanClarke, S., Hope, D., Jaffe, D. A., Copeland, S., Geiser, L., Rueth, H. M., and Sickman, J. O.: Nitrogen emissions, deposition, and monitoring in the Western United States, BioScience, 53, 391-403, 2003.

Filippa, G., Freppaz, M., Williams, M. W., and Zanini, E.: Major element chemistry in inner alpine snowpacks (Aosta Valley Region, NW Italy), Cold Reg. Sci. Technol., 64, 158-166, 2010.

Freppaz, M., Williams, B. L., Edwards, A. C., Scalenghe, R., and Zanini, E.: Labile nitrogen, carbon, and phosphorus pools and nitrogen mineralization and immobilization rates at low temperatures in seasonally snow-covered soils, Biol. Fert. Soils, 43, 519529, 2007.

Galloway, J. N., Dentener, F. J., Capone, D. G., Boyer, E. W., Howarth, R. W., Seitzinger, S. P., Asner, G. P., Cleveland, C. C., Green, P. A., Holland, E. A., Karl, D. M., Michaels, A. F., Porter, J. H., Townsend, A. R., Vosmarty, C. J.: Nitrogen cycles: past, present, and future, Biogeochemistry, 70, 153-226, 2004.

Gundersen, P., Emmett, B. A., Kjonaas, O. J., Koopmans, C. J., and Tietema, A.: Impact of nitrogen deposition on nitrogen cycling in forests: a synthesis of NITREX data, Forest Ecol. Manag., 101, 37-55, 1998. 
Helliwell, R. C., Coull, M. C., Davies, J. J. L., Evans, C. D., Norris, D., Ferrier, R. C., Jenkins, A., and Reynolds, B.: The role of catchment characteristics in determining surface water nitrogen in four upland regions in the UK, Hydrol. Earth Syst. Sci., 11, 356-371, doi:10.5194/hess-11-356-2007, 2007.

Hiltbrunner, E., Schwikowski, M., and Körner, C.: Inorganic nitrogen storage in alpine snow pack in the Central Alps (Switzerland), Atmos. Environ., 39, 2249-2259, 2005.

Hood, E., Williams, M. W., and Caine, N.: Landscape controls on organic and inorganic nitrogen leaching across an alpinesubalpine ecotone, Green Lakes Valley, Colorado Front Range, Ecosystems, 6, 31-45, 2003.

Hope, D., Billett, M. F., Milne, R., and Brown, T. A. W.: Exports of organic carbon in British rivers, Hydrol. Process., 11, 325-344, 1997.

Kopacek, J., Stuchlik, E., and Wright, R. F.: Long-term trends and spatial variability in nitrate leaching from alpine catchment lakeecosystems in the Tatra Mountains (Slovakia-Poland), Environ. Pollut., 136, 89-101, 2005.

Kuhn, M., Schellander, H., Nickus, U., and Haselhofer, J.: Seasonal development of ion concentration in a high alpine snowpack, Atmos. Environ., 32, 4041-4051, 1998.

Lafreniere, M. J. and Sharp, M. J.: A comparison of solute fluxes and sources from glacial and non-glacial catchments over contrasting melt seasons, Hydrol. Process., 19, 2991-3012, 2005.

Letey, S., Freppaz, M., Filippa, G., Stanchi, S., Cerli, C., Pogliotti, P., and Zanini, E.: Soil development along a glacial chronosequence (Pré de Bar glacier, NW Italy), Geophys. Res. Abstr., EGU2010-9182-1, EGU General Assembly 2010, Vienna, Austria, 2010.

Lewis, W. M.: Yield of nitrogen from minimally disturbed watersheds of the United States, Biogeochemistry, 57-58, 375-385, 2002.

Lipson, D. A., Schmidt, S. K., and Monson, R. K.: Links between microbial population dynamic and $\mathrm{N}$ availability in an alpine ecosystem, Ecology, 80, 1623-1631, 1999.

Lovett, G. M., Weathers, K. C., and Sobczak, W. V.: Nitrogen Saturation and Retention in Forested Watersheds of the Catskill Mountains, New York, Ecol. Appl., 10, 73-84, 2000.

Marchetto, A., Mosello, R., Tartari, G. A., Derome, J., Derome, K., Sorsa, P., König, N., Clarke, N., Ulrich, E., Kowalska, A.: Atmospheric deposition and soil solution Working Ring Test 2005. Laboratory ring test for deposition and soil solution sample analyses between the countries participating in the ICP forests level II monitoring programme, Editor: Office National de Forets, Department Recherche, ISBN 2-84207-310-X, 1-85, 2006.

Mast, M., Drever, J. I., and Baron, J.: Chemical weathering in the Loch Vale watershed, Rocky Mountain National Park, Colorado, Water Resour. Res., 26, 2971-2978, 1990.

Nemergut, D. R., Costello, E. K., Meyer, A. F., Pescador, M. Y., Weintraub, M. N., and Schmidt, S. K.: Structure and function of alpine and arctic soil microbial communities, Res. Microbiol., 156, 775-784, 2005.

Pauli, H., Gottfried, M., Reiter, K., Klettner, C., and Grabherr, G.: Signals of range expansions and contractions of vascular plants in the high Alps: observations (1994-2004) at the GLORIA*master site Schrankogel, Tyrol, Austria, Glob. Change Biol., 13, 147-156, 2007.
Psenner, R.: Chemistry of high mountain lakes in siliceous catchments of the central eastern Alps, Aquat. Sci., 51, 108-128, 1989.

Rogora, M., Arese, C., Balestrini, R., and Marchetto, A.: Climate control on sulphate and nitrate concentrations in alpine streams of Northern Italy along a nitrogen saturation gradient, Hydrol. Earth Syst. Sci., 12, 371-381, doi:10.5194/hess-12-371-2008, 2008.

Sabater, S., Butturini, A., Clement, J. C., Burt, T., Dowrick, D., Hefting, M., Maître, V., Pinay, G., Postolache, C., Rzepecki, M., and Sabater, F.: Nitrogen Removal by Riparian Buffers along a European Climatic Gradient: Patterns and Factors of Variation, Ecosystems, 6, 20-30, 2003.

Schmidt, I. K., Jonasson, S., Michelsen, A.: Mineralization and microbial immobilization of $\mathrm{N}$ and $\mathrm{P}$ in arctic soils in relation to season, temperature and nutrient amendment, Appl. Soil Ecol., 11, 147-160, 1999.

Schwikowski, M., Brutsch, S., Gaggeler, W., and Schotterer, U.: A high-resolution air chemistry record from an alpine ice core: Fiescherhorn glacier, Swiss Alps, J. Geophys. Res., 140, 709-719, 1999.

Seastedt, T. R., Bowman, W. D., Caine, T. N., McKnight, D., Townsend, A., and Williams, M. W.: The landscape continuum: A model for high elevation ecosystems, Bioscience, 54, 111-121, 2004.

Sickman, O. J., Melack, J. M., and Stoddard, J. L.: Regional analysis of inorganic yield and retention in high-elevation ecosystems of the Sierra Nevada and Rocky Mountains, Biogeochemistry, 57-58, 341-374, 2002.

Taylor, P. G. and Townsend, A. R.: Stoichiometric control of organic carbon-nitrate relationships from soils to the sea, Nature, 464, 1178-1181, 2010.

Tockner, K., Malard, F., Uehlinger, U., and Ward, J. V.: Nutrients and organic matter in a glacial river-floodplain system (Val Roseg, Switzerland), Limnol. Oceanogr., 47, 266-277, 2002.

Traaen, T. S. and Stoddard, J. L.: An Assessment of Nitrogen Leaching from Watersheds included in ICP on Waters, NIVA Report 86001, Oslo, 1995.

Walther, G. R., Beibner, S., and Burga, C. A.: Trends in the upward shift of alpine plants, J. Veg. Sci., 16, 541-548, 2005.

Williams, M. W., Baron, J., Caine, N., Sommerfeld, R., and Sanford, R.: Nitrogen saturation in the Colorado Front Range, Environ. Sci. Technol., 30, 640-646, 1996.

Williams, M. W., Hood, E., and Caine, N.: The role of organic nitrogen in the nitrogen cycle of a high elevation catchment, Colorado Front Range, USA, Water Resour. Res., 37, 2569-2582, 2001.

Williams, M. W., Barnes, R. T., Parman, J. N., Freppaz, M., and Hood, E.: Stream Water Chemistry along an Elevati onal Gradient from the Continental Divide to the Foothills of the Rocky Mountains, Vadose Zone J., 10, 900-914, 2011. 